\title{
Super Jabber Game Development in Increasing Learning Interest in Kindergarten Students in Medan
}

\author{
Ernida Eva Saulina Tamba \\ Department of Sport Education Post \\ Graduate Program \\ Universitas Negeri Medan (UNIMED) \\ Medan, Indonesia \\ evatamba845@gmail.com
}

\author{
Suprayitno \\ Department of Sport Education Post \\ Graduate Program \\ Universitas Negeri \\ Medan (UNIMED) Medan, Indonesia
}

\author{
Amir Supriadi \\ Department of Sport Education \\ Post Graduate Program \\ Universitas Negeri Medan (UNIMED) \\ Medan, Indonesia
}

\begin{abstract}
Research and development of super jabber games is applied to the interest in learning in kindergarten children, specifically there are several objectives, among others: 1) To obtain in-depth information about the process of implementing basic motion learning in kindergarten. 2) Develop and implement a super jabber game on the learning interests of kindergarten students. 3) Obtain empirical data about the effectiveness, efficiency and attractiveness of the development of the super jabber game in learning motion. The final goal of this development research is to produce a product in the form of a game module that contains a super jabber game with text-based media for kindergarten children, so that it can complement existing learning at this time. This research was conducted in several kindergartens in Medan. The research treatment was carried out by adjusting school schedules or school hours. The time of this research was carried out for one month, which was when the seminar proposal was finished. Subjects or users who are targeted in the research of the development of super jabber games on the interest in learning in kindergarten children Subjects in the small group in this study were Ar Raudah Kindergarten students with a total of 12 students who had the age range of 4-5 years. Subjects in the large group in this study in Raudhatul Atfal Kindergarten with a total of 24 students.
\end{abstract}

Keywords: Super Jabber, Games, Kindergarten Children.

\section{INTRODUCTION}

Early childhood education (PAUD) is one of the preschool educational institutions which is expected to be a facilitator for children's overall development. Education for early childhood is the provision of efforts to stimulate, guide, nurture and provide learning activities that will produce children's abilities and skills. Early childhood education is an education that is carried out on newborns up to 6 years. Childhood is usually always guided in PAUD or kindergarten.

Childhood is a time when you still tend to play. As stated by Tedjasaputra (in Nurhayati 2015: 34), that play activities are most favored by children in pre-school, and part of the time children are used to playing. Play activities in children can be divided into two, namely playing without using tools and also playing using tools.
The meaning of play can be achieved if it is supported by an adequate environmental arrangement such as the availability of various and deep playing instruments according to the age of the child. Playing using a game can fulfill all aspects of a child's happiness. When children feel happy, the child's brain growth is increasing perfectly so that it makes it easier for children to do the learning process, therefore the authors are interested in making games that involve children's cognitive and psychomotor. Various studies conducted by various experts conclude that children's education from an early age can improve performance and increase work productivity in adulthood. Once the importance of early childhood, Santrock and Yussen (in Solehuddin 2000: 2), argued that early age is a period filled with important and unique events (a very eventful and unique priod of life) that laid the foundation for people in adulthood. Kindergarten age is one of the age ranges in early childhood, namely the age of 4 to 6 years. This period is referred to as the golden period, because the child's valuable developmental opportunities.

Based on various aspects of development above, cognitive development is an important one to develop because it has the aim of developing children's thinking ability to be able to process their learning gains, be able to find various alternative problem solving, help children to develop their mathematical logic and knowledge of space and time, and has the ability to group and prepare to develop the ability to think carefully. This is in line with the opinion of Gunarsa (in Dewi 2005: 11), revealing that cognitive is a mental function that includes perceptions, thoughts, symbols, reasoning, and problem solving

In the TK curriculum (2004), it is explained that the basic competencies that must be mastered in the field of cognitive development are that children are able to recognize simple concepts in daily life. This is in line with Minister of Education Regulation No. 137 of 2014 concerning PAUD National Standards there are various aspects that must be achieved by children which include moral and religious values, physical motor, cognitive, language, social-emotional and arts. 
With regard to motorics, motorics are used to describe the behavior of movements performed by the human body. Motor control is usually used in the fields of psychology, physiology, neurophysiology and sports. The process of growth and development of a child's mobility. Basically, development. Motor development is this developed in line with the maturity of the nerves and muscles of children. So, every movement as simple as anything, is the result of complex patterns of interaction of various parts and systems in the body that are controlled by the brain. Motor skills are body movements or body parts that are intentional, automatic, fast and accurate. These movements are a series of coordination of hundreds of complex muscles. These motor skills can be grouped according to the size of the muscles and related body parts, namely gross motor skills and fine motor skills.

Observations were made on students which included running, jumping, jumping, throwing, and turning. These movements are movements that are often done by early childhood or kindergarten students. Based on observations in several kindergartens in Medan City that there are problems:

1) Where from all the examples of movements chosen by researchers, apparently only a few students understood the instructions that were carried out. And students are not interested if the material is carried out just to do the movements without the game.

2) Based on observations of teachers and researchers that kindergarten children have been attacked by a game virus on smartphones, observations made several months by teachers where the conversation of students during recess usually discusses games on smartphones and this is a negative influence of technology that has attacked the thinking of children. Where should children play at his age but instead use a smartphone without parental guidance. Smartphone addiction is a very complex problem if it occurs in early childhood.

3) Based on the observation of researchers that kindergarten teachers do not apply the concept of playing games that are interesting so as to provide basic motion learning it will be very difficult to provide stimulus to students and the learning objectives will not be achieved to the maximum.

4) Lack of interest in learning about things related to the move.

If the physical development of children gets training in accordance with the characteristics of the child, then the tendency of children will be easier to achieve the desired sport. The child's motor skills begin with doing basic exercises. Basic motion is very important in an effort to instill the right basis in moving. Therefore it is necessary to have a discussion about what are the basic movements that are important and must be mastered by children.
Super Jabber game is a game on Android mobile where the game contains an adventure in passing obstacles. And in this game it is played in 1 person. In this study the Super Jabber game was adopted from a game that is on an Android phone. And applied with motion where there are routes that have obstacles in the form of boxes that must be passed, plastic balls, flags and hulahup which are obstacles. And resolved as soon as possible. This game is implemented in order to create student interest in learning about motion learning.

Gallahie in Novi (2016: 25) said that play is the most basic needs of children when children interact around the world, through play they do. Playing the alphabet of an activity that is directly and spontaneously carried out by a child with other people or by using the surrounding objects with pleasure, voluntary and imaginative, and by using his feelings, hands, or all members of his body.

Hartley, Frank, and Goldensen (in Novi, 2016: 26-27) mentioned eight play functions for children, which are as follows.

a) Imitate something done by an adult. For example, imitating mother cooking, doctors treating sick people, mothers shopping at the market, father repairing broken motorbikes, and so on.

b) To perform various roles that exist in real life, such as teachers teaching in class, drivers driving buses or trucks, farmers hoeing in the fields, etc.

c) To reflect relationships with family and real life experiences. For example, mothers bathe younger siblings, fathers read people, brothers do schoolwork, brothers listen to the radio, and so on.

d) To channel strong feelings such as banging cans, patting water, and so on.

e) To release unacceptable impulses, such as acting as a thief, being a bad boy, traffic violators and so on.

f) For flashbacks of the usual roles, such as bathing, breakfast, taking public transportation, and others.

g) Reflecting growth, such as stronger leg growth, increasing body height, can increasingly run faster.

h) To solve problems and try various solutions to problems, such as decorating a room, preparing food, and so on.

Giving lessons on children's games to students will influence (Soedjadi, 1979: 94-95):

1. Physical health and strength. The effect of play on a child's physical development and growth will be as common as the effect of sports in general on the culprit. But more than that children's play also influences the development of the children's five senses sharply, such as the development of the 
sense of touch, the development of vision by observation, interpreting distance and so on, interpreting based on changes in expression (facial expression) hearing development and even also kissing and taste.

2. Physical fitness. With an increase in the function of organs will result in increased physical fitness to carry out daily activities that are always increasing.

3. Mastery of language. By playing children must communicate, one of communication tools is language, to be satisfied they play, they must try to master the language they use to play. In playing, it is not uncommon for children to have dialogues, for example: buying and selling games, the beetle asking for flowers and so on. Puzzle games except improving thinking are also worth developing language acquisition.

4. A sense of art and beauty. It is not uncommon that in children's play must be accompanied by movements in accordance with the accompanying song or the song they are singing this means it will give an opportunity to the child or is a situation that allows an increase in motion art, mastery of rhythm and sound art. And in certain games even children have to recite poetry, rhymes, race to love the language arts. It is a pity that songs for children's games in Indonesian are very lacking or even non-existent, but songs for children's games in local languages are very many. This is the duty of educators to compose songs for games in Indonesian or at least Indonesian songs for local games for our mutual benefit.

5. Good character. With the game, the child's personality development will forget the state of self, because there are tasks, self-control, self-criticism, discipline, courage, determination, tenacity, respect the rules, respect friends, respect the referee and others.

6. Children's social sense. Children play will get to know the environment, know themselves, know the tools used to play, know the opponent. Thus to obtain pleasure the child will be aware to maintain and respect the environment, tools and playmates. Because children's games are taught in the context of education, then naturally a teacher must be able to choose a game that has high courage towards physical development and growth, according to the child's situation.

The explanation above can be concluded that playing will build aspects that exist in children one of which is feeling happy. This is certainly related to interest in learning. Interest is a feeling of preference and a feeling of interest in a thing or activity, without being told. Interest is basically the acceptance of a relationship between oneself and something outside of oneself. The stronger or closer the relationship, the greater the interest (Slameto, 2010: 180).

Big interest influence on learning activities. Students who are interested in learning movement seriously like studying diligently, feel happy to follow the presentation of the lesson, and can even find difficulties in learning to solve practice and practice questions because of the attraction gained by learning motion. Students will easily memorize lessons that interest them. Interest is closely related to motivation. Motivation arises because there is a need, so does interest, so that it is appropriate if the interest is a motivational tool. The learning process will run smoothly if accompanied by interest. Therefore, the teacher needs to arouse students' interest so that the lessons given are easy for students to understand.

Based on the description above, the researcher will conduct a study entitled "Development of the Super Jabber Game in Increasing the Interest of Kindergarten Students in Medan"

\section{RESEARCH METHODS}

In the research of super jabber game development towards learning interest in kindergarten children is a process used to develop and validate learning products. Research and development in learning uses the Research \& Development (R\&D) development model of Borg \& Gall (1983: 776) which consists of ten steps including: (1) Conducting research and information gathering (literature review, subject observation, preparation main issue report) (2) Planning (defining skills, formulating goals, determining the order of teaching, and small-scale trials) (3) Developing the initial product forms (preparing teaching materials, preparing handbooks, and evaluation equipment) (4) Conducting initial field testing (using 6-12 subjects) (5) conducting a revision of the main product (in accordance with the recommendations of the initial field test results) (6) conducting a main field test (with 30-100 subjects. (7) conducting a product revision (based on the suggestions and results of the main field trials) (8) Field tests with 40-200 subjects (9) Revision of the final product (10) Making a report on the product in a journal, working with penerbit which can carry out commercial distribution.

\section{DATA ANALYSIS TECHNIQUE}

The research and development of super jabber games is applied to the interests of learning in kindergarten children, specifically there are several objectives including:

1. To obtain in-depth information about the process of implementing basic motion learning in kindergarten.

2. Developing and implementing a super jabber game to kindergarten students' learning interests.

3. Obtain empirical data about the effectiveness, efficiency and attractiveness of developing the super jabber game in learning motion.

The final goal of this development research is to produce a product in the form of a game module that contains a super jabber game with text-based media for kindergarten children, so that it can complement existing learning at this time. 


\section{REFERENCE}

[1] Borg. W. R \& Gall, M. D. 1983. Educational Research An Introduction. New York: Longman.

[2] Imam Soedjadi. 1979. Game and Methodology Book I. Jakarta: Ministry of Education and Culture.

[3] Imam Soedjadi. 1979. Game and Methodology Book II. Jakarta: Ministry of Education and Culture.

[4] Novi Mulyani. 2016. Super Fun Traditional Indonesian Children Games. Yogyakarta: DIVA Pres.

[5] Slameto 2010. Learning \& Influencing Factors. Jakarta: PT Rineka Cipta. 